\title{
Mechanisms of food partitioning and ecomorphological correlates in ten fish species from a tropical estuarine marine protected area (Bamboung, Senegal, West Africa)
}

\author{
Djibril Faye ${ }^{1,2 *}$, François Le Loc' ${ }^{3}$, Omar T. Thiaw ${ }^{1}$ and Luis Tito de Moraïs ${ }^{2}$ \\ ${ }^{1}$ IUPA, Université Cheikh Anta Diop de Dakar, BP. 45784 Dakar Fann, Sénégal. \\ ${ }^{2}$ IRD, UMR 195 LEMAR/RAP (IRD/CNRS/UBO), Centre de Bel Air, BP 1386, Dakar, Sénégal. \\ ${ }^{3}$ IRD, UMR 212 EME (IRD/IFREMER/UM2), Centre de Recherche Halieutique Méditerranéenne et Tropicale, Avenue \\ Jean Monnet, B.P. 171, 34203 Sète Cedex, France. \\ Accepted 18 October, 2011
}

\begin{abstract}
Ecomorphological correlates were sought among 10 fish species of different life history traits in a tropical estuary. Results from gut contents analysis showed that fish species were classified into four trophic groups including detritivores, zooplanktivores, benthivores, piscivores and macrocarnivores. Resource partitioning among fishes was under the influence of their morphological attributes. Detritivores and zooplanktivores were both characterized by the possession of long gill raker and a wide mouth. The suction feeding mode has been hypothesized to explain the morphological convergence. Detritivorores have additionally a long digestive tract, long pectoral and dorsal fins, a short caudal fin, while zooplanktivores have otherwise big eyes. Benthic invertebrate feeders had big eyes, long dorsal fins, a long head prolonged by protrusive jaws. Piscivores and macrocarnivores were both characterized by the possession of a deep caudal peduncle, up-positioned eyes and a wide and deep mouth. However, the mouth size was more pronounced in strict piscivores, while macrocrustacean feeders had a longer head and long pectoral and dorsal fins. This study corroborates the consistency of the relationships between morphology and ecology in fish assemblages of tropical estuarine systems. Whatever the prey functional type, benthic foraging fishes were characterized by the possession of long paired fins.
\end{abstract}

Key words: Diet, morphology, resource partitioning, life history traits.

\section{INTRODUCTION}

How fish functional morphology shapes species coexistence and assemblage diversity patterns is a fundamental issue in ecological research (Ferry et al., 2003; Rice and Wesneat, 2005; Ferry et al., 2008). In ecological systems, species may partition resources through trophic, spatial or temporal dimensions (Pianka, 1969). Nevertheless, trophic niche partitioning has been recognized as the main factor structuring communities (Schoener, 1974; Ross, 1986; Sibbing et al., 1998). In particular, fish communities' structure is more difficult to

*Corresponding author. E-mail: fayecgasar@yahoo.fr. Tel: +221338645981. Fax: +221338645981. predict as many fish species change their diet in relation to food resources availability and ontogeny (Sibbing et al., 1994; Piet, 1998). Yet, species potential niche is constrained by morphology (Wainwright, 1994; Norton et al., 1995). Thus, morphological characters are often suited to determine the mechanisms of resource partitioning among species in communities (Wikramanayake, 1990; Adite and Winemiller, 1997). Ecomorphological research is concerned with the patterns of co-variation between morphology and ecological performance of organisms (Norton et al., 1995). This approach has been widely used to study trophic organization and resource partitioning (Norton and Brainerd, 1993; Adite and Winemiller, 1997; Xie et al., 2001) and habitat specialization (Wikramanayake, 1990; Motta et al., 1995; Willis et 
al., 2005; Chuang et al., 2006) in fish assemblages.

In recent years, a burgeoning literature indicating the performance of ecomorphological studies in characterizing fish communities in South American tropical estuaries has emerged (Ponton and Périgoux, 2000; Pouilly et al., 2003; Ibañez et al., 2007; Ferreira et al., 2007; Medeiros and Ramos, 2007). In contrast, West African tropical estuaries' food webs are poorly known, and trophic interactions studies based on ecomorphological approaches are scarcer (Adite and Winemiller, 1997; Hugueny and Pouilly, 1999). The present study examines the relationship between diet and morphology and the mechanisms of resource partitioning in some fish species of different life history traits in a small creek in the Sine-Saloum estuary (the Bamboung bolong). Fish assemblage in the whole estuary is characterized by a relative high diversity (114 species) according to Diouf (1996) and high seasonal spatio-temporal dynamics (Simier et al., 2004). Several decades of heavy fishing pressure have resulted in a loss of over $40 \%$ of fish biomass and a decrease of 0.11 (2.97 to 2.86) in mean trophic level (Ecoutin et al., 2010). In 2003, a marine reserve was created in the Bamboung creek in order to reduce the effect of fishing and to restore the local fish assemblage. The marine reserve located in the central zone of the estuary provides natural ecological conditions, justifying the choice of the site for the present study. Published studies relative to fish assemblage in the studied creek remained very scarce (Sow and Guillard, 2010).

According to unpublished data from our research team, 72 species have been found in the creek since the marine reserve implementation while less than 50 were regularly found prior to the creation of the marine reserve. The food web in the marine reserves is characterized by a strong seasonal variability in food-chain length and in species composition (Faye et al., 2011). However, little is known about the mechanisms of resources partitioning. The present study determined the relationship between diets and morphology in some key fish species in the Bamboung's marine reserve. First, the preliminary fish's trophic guild categorization based either on field macroscopic examination of gut contents or on early studies (Diouf, 1996) was revised. We specifically address: (1) how does trophic niche overlap between species having different life history traits? (2) What is the role of morphological variations in shaping the local fish functional niches?

\section{MATERIALS AND METHODS}

\section{Study site}

The Bamboung marine reserve $\left(13^{\circ} 50 \mathrm{~N}-16^{\circ} 33 \mathrm{~W}\right)$ is located in a small creek in the core of the Sine-Saloum Delta in the West of Senegal (Figure 1). The creek is $15 \mathrm{~km}$ long, its width in the middle zone reaches $500 \mathrm{~m}$ for a maximum depth of $15 \mathrm{~m}$. Local climate is characterized by the alternation of a dry and warm season and a wet and moderately cool season. Vegetation on the creek banks is dominated by mangroves, mainly constituted of Avicennia racemoza and Rhizophora mangle. The lower average salinity values (32) occurred at the end of the rainy season and the highest values (43) at the end of the dry season. The average temperature varied from $26^{\circ} \mathrm{C}$ in March (intermediate season) to $31^{\circ} \mathrm{C}$ at the end of the rainy season (Faye et al. 2011).

\section{Morphological variables}

Morphological measurements were realized on specimens caught in the marine reserve in March and May 2008. Fishes were collected using a purse seine net, and identified to the species level. The choice of species was primarily based on their trophic categorizations defined in Diouf (1996) and secondly on their occurrence as determined from the long term experimental catches performed by our research team and recently published by Ecoutin et al. (2010). The spatio-temporal distribution of species in the estuary depends on their life history traits. Some species accomplish all their life cycle (breed and growth) in the estuary and others do not breed there, but use the estuary as a nursery. According to these criteria, Albaret (1994) has defined a bioecological categorization of West African fishes (Table 1). According to this classification, fish species are grouped into two broad categories around a central point constituted by strict estuarine species (Es). The first category includes species with marine affinities whereas the second one is composed by species with continental affinities. Marine affinity species include: the estuarine species of marine origin $(\mathrm{Em})$ which may reproduce either in ocean or in estuary, the marine-estuarine species (ME) which had a wide spatio-temporal distribution in estuary but do not breed there and complementary species which are either accessory (Ma) or occasional (Mo) in estuaries. Species belonging to the freshwater gradient have never been captured in the creek and are not represented in the present study, nevertheless a detailed description of their bioecological categorization may be found in Albaret (1994, 1999).

Eighteen morphological variables were measured based on Gatz (1979), Winemiller (1991), and Adite and Winemiller (1997). A numeric vernier calliper (precision $=0.1 \mathrm{~mm}$ ) was used to measure: mouth diameter MD (maximum horizontal distance when mouth was full opened), mouth height $\mathrm{MH}$ (vertical distance between the tips of the mandible and the maxillary jaws), body width BW (maximum horizontal distance between the two lateral sides), mouth protrusion length PrL (protrusive upper jaw pulled). A digital image of the lateral profile of each specimen was then taken with a camera for later other morphological measurements. Then, the digestive tract and the first branchial arch were removed and preserved in formaldehyde (10\%). At the laboratory, gut length (GuL) was measured with a metallic ruler, and gill raker maximal length (GrL) was determined using a microscope fitted with a micrometer. The remaining morphological variables were measured on photographs by means of a free access digital processing software (Image-J, http://rsb.info.nih.gov./ij): standard length SL (from the tip of the upper jaw to the last vertebra), dorsal fin length $\mathrm{DfL}$, pectoral fin length $\mathrm{PfL}$, caudal fin length $\mathrm{CfL}$, head length $\mathrm{HL}$, eye diameter ED, caudal fin depth CfD, mouth position MP, caudal peduncle depth $\mathrm{CpD}$, eye position $\mathrm{EP}$, body depth $\mathrm{BD}$ and head depth HD. Full description of the morphometric methods of distance measurements may be found in Winemiller (1991).

Linear morphometric distances were transformed into ratios following the methods of Winemiller (1991) and Adite and Winemiller (1997). Such transformations allow the removal of the body size effect and the reduction of linear distances into shape components which had a more functional interpretation. Fourteen out of the 18 measured morphometric distances were transformed into ratios, and four other (standard length, body depth, body width 


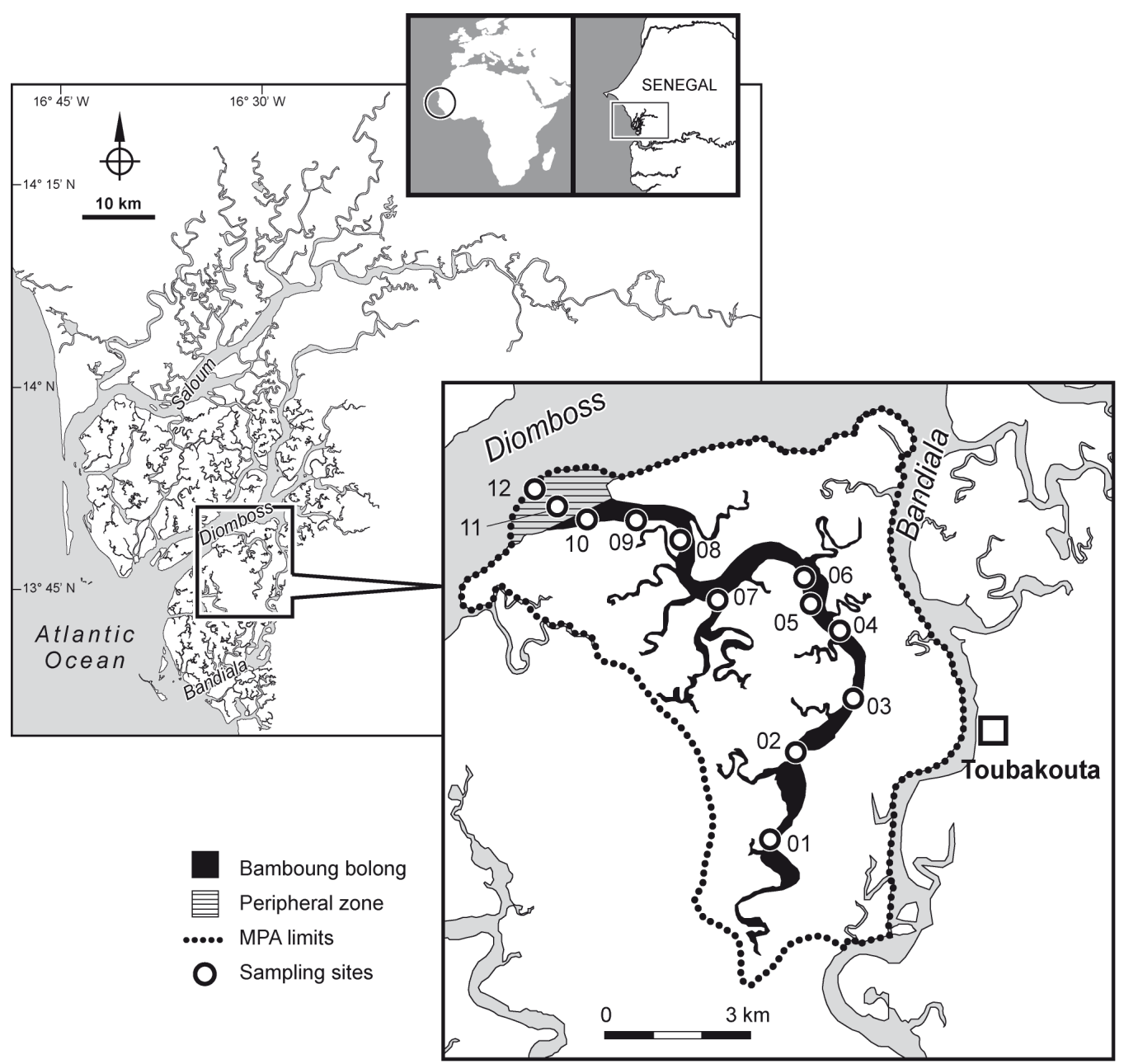

Figure 1. Localisation of the Bamboung creek and the Marine Protected Area boundaries. The circles indicate the location of the 12 sampling sites.

Table 1. Fishes species' families, scientific names, species codes and their bioecological categories based on Albaret (1994, 1999).

\begin{tabular}{llcc}
\hline Family & Species & Codes & Bio-cat \\
\hline Ariidae & Arius latiscutatus (Günther, 1864) & AGA & ME \\
Clupeidae & Ethmalosa fimbriata (Bowdich, 1825) & EFI & Em \\
& Sardinella maderensis (Lowe, 1838) & SEB & ME \\
Elopidae & Elops lacerta (Valenciennes, 1847) & ELA & ME \\
& & & \\
Gerreidae & Eucinostomus melanopterus (Bleeker, 1863) & GME & ME \\
& Gerres nigri (Günther, 1859) & GNI & Es \\
Lutjanidae & Lutjanus goreensis (Valenciennes, 1830) & LGO & Ma \\
Monodactylidae & Monodactylus sebae (Cuvier, 1829) & PSB & Es \\
Haemulidae & Pomadasys perotaei (Cuvier, 1830) & PPE & Em \\
Cichlidae & Tilapia guineensis (Bleeker, 1862) & TGU & Es \\
\hline
\end{tabular}

Es: Strictly estuarine species; Em: estuarine species of marine origin; ME: marine-estuarine species; Ma: marine species accessory in estuaries. 
Table 2. Volumetric proportions of the nine functional prey categories identified in the ten species.

\begin{tabular}{|c|c|c|c|c|c|c|c|c|c|c|c|}
\hline Species & $\mathbf{n}$ & Bth_Int & Fish & Insect & Mc_crst & Moll & PIts & Subst & Unprey & Zkpl & Trophic groups \\
\hline Arius latiscutatus & 91 & 14.7 & 53.1 & 0.5 & 17.4 & 9.6 & 0.4 & 0.8 & 2.5 & 0.0 & Macrocarnivores \\
\hline Ethmalosa fimbriata & 100 & 0.2 & 0.0 & 0.0 & 0.0 & 0.9 & 1.6 & 89.5 & 0.0 & 7.5 & Detritivores \\
\hline Elops lacerta & 15 & 0.0 & 100 & 0.0 & 0.0 & 0.0 & 0.0 & 0.0 & 0.0 & 0.0 & Macrocarnivores \\
\hline Eucinostomus melanopterus & 58 & 71.8 & 0.0 & 0.0 & 2.2 & 21.6 & 0.0 & 0.0 & 4.2 & 0.0 & Benthivores \\
\hline Gerres nigri & 26 & 22.3 & 0.0 & 0.0 & 0.0 & 75.0 & 0.7 & 0.5 & 1.2 & 0.0 & Benthivores \\
\hline Lutjanus goreensis & 20 & 0.00 & 20.2 & 0.0 & 76.1 & 1.0 & 0.0 & 0.0 & 2.5 & 0.0 & Macrocarnivores \\
\hline Pomadasys perotaei & 29 & 14.7 & 0.0 & 0.0 & 0.0 & 83.5 & 0.4 & 0.0 & 1.2 & 0.0 & Benthivores \\
\hline Monodactylus sebae & 54 & 7.3 & 20.2 & 2.6 & 9.4 & 1.1 & 20.0 & 4.4 & 14.9 & 7.8 & Omnivores \\
\hline Sardinella maderensis & 28 & 2.3 & 0.0 & 0.0 & 0.0 & 0.0 & 0.0 & 0.0 & 7.7 & 89.9 & Zooplanktivores \\
\hline
\end{tabular}

Bth_Int; Benthic invertebrates; Fish: fishes, Insect: insects; Mc_crst: macrocrustaceans; Moll: molluscans; Subs: substratum; Unprey: unidentified prey; Zkpl: zooplanktivores; n: number of samples with full stomachs. Trophic groups are referred to the newly adopted trophic categorization.

and head depth) served only for standardization. Head depth was used to standardize gill raker length, eye position and mouth position. Body depth was the denominator for caudal peduncle depth and mouth height. Body width served as denominator for mouth width and eye diameter was divided by head length. Standard length was used to standardize the seven remaining morphometric distances. These fourteen ratios (Appendix 1) are functionally related to feeding processes (mode of prey capture and assimilation) and locomotive mechanisms. More information in the functional interpretations of these ratios can be found in the early ecomorphological studies (Gatz, 1979; Wikramanayake, 1990; Winemiller, 1991).

\section{Ecological variables}

Specimens used for gut content analysis were collected in the marine reserves from March to October 2007. The content of each stomach was removed and its volume was determined using the technique of water displacement (Winemiller, 1990). Prey items were then identified to the lowest taxonomic level under a binocular magnifying glass, taking into account the state of digestion. Large individual food items were blotted dry on paper and their volume estimated. Small items were counted and the volume of individuals was estimated in comparison to known volumes. For detritivorous fish with long digestive tract, a section of the intestine was dissected and analyzed. The volume of the subsample and that of the entire digestive tract being known, the gut composition of each specimen was deduced by extrapolation (Winemiller, 1990). The volumetric proportions of identified items were calculated following the methods given in Winemiller et al. (1995), and Adite and Winemiller (1997). The total volumes of each item were obtained by summing individual volumes across our samples. The volumetric proportion of each item was then calculated on the basis of the total volume of food eaten by each consumer.

\section{Data analysis}

Diet overlap between two consumers ( $\mathrm{j}$ and $\mathrm{k}$ ) was estimated using the simplified Horn-Morisita index (Horn, 1966) calculated following this equation:

$$
\Phi_{J K}=\frac{2 \sum_{\mathrm{i}=1}^{\mathrm{n}} \mathrm{P}_{\mathrm{ij}} \mathrm{P}_{\mathrm{ik}}}{\sum_{\mathrm{i}=1}^{\mathrm{n}} \mathrm{P}^{2}{ }_{\mathrm{ij}}+\sum_{\mathrm{i}=1}^{\mathrm{n}} \mathrm{P}^{2}{ }_{\mathrm{ik}}}
$$

where, $\Phi \mathrm{jk}$ indicated the values of the index, $\mathrm{Pij}$ and Pik represented respectively the volumetric proportion of prey category in the diet of species $\mathrm{j}$ and $\mathrm{k}$. The numeric application of the index was performed using the library vegan running with $R$ ( $R$ Development Core Team, 2010).

The values of this index ranged from 0 (full overlap) to 1 (no overlap between species), and values of index ranging between 0 and 0.4 are indicative of intense overlap (Krebs, 1998). Prior to analysis, identified items were grouped into 8 general categories reflecting their functional type (Appendix 2). Functional prey categorization was based on the criteria defined by Sibbing and Nagelkerke (2001), and Wainwright and Bellwood (2001). According to these authors, prey items may be classified based on their position in the water column, their size and their hardness. The prey items which were not taxonomically identified and mashed food were gathered into a single category termed the "unidentified prey". The functional property of this category being unknown it was removed from the data before performing the multivariate analysis. The co-variation between the morphological and the dietary matrix was examined using a canonical correspondence analysis (CCA) which is a multivariate technique of ordination (Ter Braak, 1986). The CCA allow linear combinations of each of the two datasets (morphological and ecological variables) producing canonical variables. Thus, canonical explanatory variables are constrained to be maximally correlated, sorting a co-structural pattern in the community data. The morphological matrix comprises 14 standardized ratios, these latter deriving from the average morphometric distances measured in 5 specimens of each species. The ecological matrix is formed by the volumetric proportions of each of the 8 functional categories (the replicate number for each species are indicated in Appendix 2). Statistical analyses were realized using the ade 4 package running with the $R$ (version $R$ 2.11. 1) software (R Development Core Team, 2010). Significant canonical coefficients were defined as $(\mathrm{cc} \geq|0.4|)$ according to Rakocinski et al. (1996).

\section{RESULTS}

\section{Diet composition}

Fish species can be classified into five trophic groups based on the proportions of the different functional prey categories (Table 2). The detritivore was the first trophic group and were composed of Tilapia guineensis (Bleeker, 1862) and the juveniles of Ethmalosa fimbriata (Bowdich, 1825), which fed mainly on substratum associated with 
Table 3. Matrix of diet overlap between the ten fish species based on the Horn-Morisita dissimilarity index calculated using the volumetric proportions of the nine functional prey categories.

\begin{tabular}{lccccccccc}
\hline & AGA & EFI & GME & GNI & LGO & PPE & SEB & PSB & ELA \\
\hline EFI & 0.98 & & & & & & & & \\
GME & 0.70 & 0.99 & & & & & & & \\
GNI & 0.77 & 0.98 & 0.45 & & & & & & \\
LGO & 0.49 & 0.99 & 0.96 & 0.98 & & & & & \\
PPE & 0.80 & 0.98 & 0.55 & $\mathbf{0 . 0 0}$ & 0.98 & & & & \\
SEB & 0.99 & 0.91 & 0.97 & 0.99 & 0.99 & 0.99 & & & \\
PSB & $\mathbf{0 . 3 7}$ & 0.88 & 0.80 & 0.91 & 0.66 & 0.94 & 0.80 & & \\
ELA & $\mathbf{0 . 2 0}$ & 1.00 & 1.00 & 1.00 & 0.75 & 1.00 & 1.00 & 0.60 & \\
TGU & 0.98 & $\mathbf{0 . 0 4}$ & 0.99 & 0.98 & 1.00 & 0.99 & 0.99 & 0.77 & 1.00 \\
\hline
\end{tabular}

See Table 1 for species codes.

plants. Benthophageous species constituted the second trophic group. This group included Pomadasys perotaei (Cuvier, 1830), Eucinostomus melanopterus (Bleeker, 1863) and Gerres nigri (Günther, 1859). The diet of $P$. perotaei and $G$. nigri were dominated by molluscs, while E. melanopterus fed mainly on benthic crustaceans. Sardinella maderensis (Lowe, 1838) fed mainly on zooplankton associated with low proportions of benthic invertebrates and represented the zooplanktivore trophic guild. Elops lacerta (Valenciennes, 1847), Lutjanus goreensis (Valenciennes, 1830) and Arius latiscutatus (Günther, 1864) had a diet composed of over $50 \%$ of either fishes or macrocrustaceans and were classified as macrocarnivores. Monodactylus sebae (Cuvier, 1829) had the widest diet spectra which included all the eight functional preys and was classified as a generalist omnivorous species.

\section{Diet overlap}

The highest pairwise diet overlaps were recorded for $P$. perotaei and $G$. nigri which fed mainly on molluscs. The substrate feeders as the tilapia ( $T$. guineensis) and the young of $E$. fimbriata have the second higher overlapping diets (Table 3). Significant overlap indices were also found between the macrocarnivores $E$. lacerta and $A$. latiscutatus and between this latter and $M$. sebae (Table 3).

\section{Relationship between diet and morphology}

For the four first CCA axes, the eigenvalues representing the importance of each of them were respectively 0.9 , $0.81,0.80$ and 0.4 (total inertia= 2.91). The first four axes of the CCA explained $87 \%$ of the total variance. Position of species and that of food categories on the factorial space constituted by the combination of the four CCA axes are plotted on Figures 2 and 3 . More, loadings of the unconstrained ecological variables and canonical correlation coefficients with morphological variables are reported in Table 4. Absolute cumulative eigenvalues ranged from 0.46 to 2.35 , representing respectively 15.8 and $80.75 \%$ of the total inertia. The first axis of the CCA explained $26 \%$ of the total variance. This axis was on the one hand positively correlated with caudal fin length and protrusion length and on the other hand negatively correlated with gill raker length, gut length and mouth width. Fish species which fed on detritus (substratum and plants) appeared on the negative branch on this axis and were then characterized by the possession of long gill raker, a long digestive tract, a wide mouth, a short caudal fin and non protrusive jaws. The second CCA axis represented $24 \%$ of the total variance.

Piscivorous fishes and macrocrustacean predators scored high on the positive branch of the second CCA axis and were characterized by the possession of a deep caudal peduncle, up-positioned eyes, and a wide and high mouth. Benthic invertebrate feeders and molluscivores were positioned in an intermediate position between the positive branch and the negative one of respectively the first and the second CCA axes. They were characterized by the possession of big eyes, protrusive jaws and long caudal fins. The third CCA axis represented $24 \%$ of the total variance and was positively characterized by benthophages (detritivores and benthic invertebrate feeders) which possessed either a long digestive tract or long pectoral and dorsal fins. They were opposed to zooplanktivores which appeared on the negative branch of the same axis and were characterized by an up-positioned mouth. Zooplanktivores were also characterized by the possession of a large mouth and long gill raker on axis 1 and that of big eyes on axis 2 . The fourth axis was defined by the opposition between the strict piscivores and macrocarnivores. The strict piscivorous behaviour was fully correlated with the possession of a large and high up-positioned oral gap, while macrocarnivores had a long head and long pectoral and dorsal fins. 


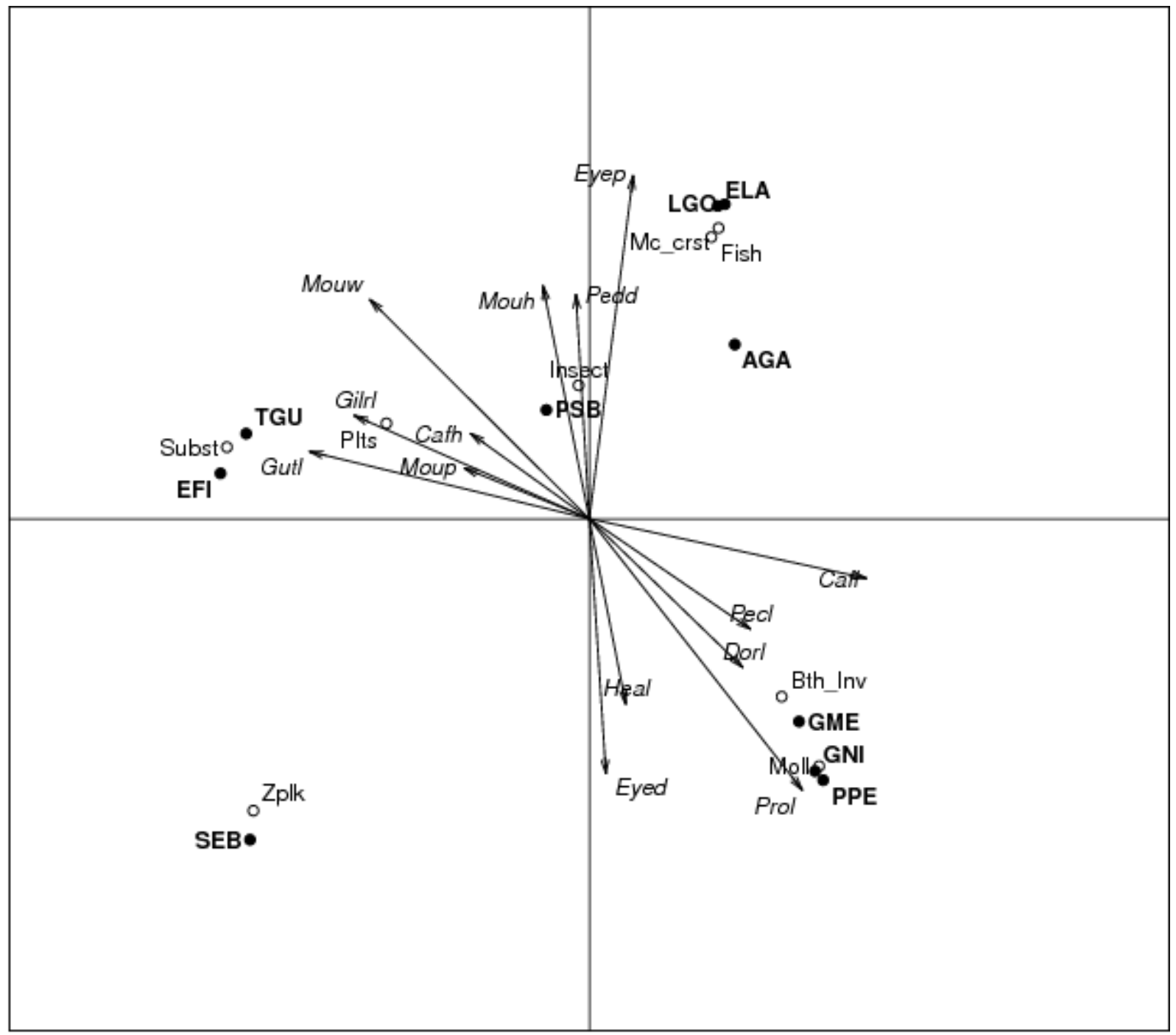

Figure 2. Ordination of the first two canonical correspondence analysis (CCA) axes based on dietary and morphological variables. See Table 1 for species codes; Table 2 for functional prey type codes. Code signification for morphological variables : Cafh : Caudal fin height; Cafl : Caudal fin length; Dorl : Dorsal fin length; Eyed: Eye diameter; Eyep : Eye position; Gilrl : Gill raker length; Gutl : Gut length; Heal : Head length; Mouh; Mouth height; Moup, Mouth position; Mouw, Mouth width; Pecl, Pectoral fin length; Pedd, Pectoral fin depth; Prol, Protrusion length.

\section{DISCUSSION}

\section{Trophic ecology}

Detritivorous species includes the juveniles of E. fimbriata and $T$. guineensis. Our observations relative to the diet of $T$. guineensis is consistent with the conclusion of Adite and Winemiller (1997) who found that in Benin's lagoon, the diet of this species included more than $75 \%$ of detritus. Offem et al. (2009) found that cichlid species among which $T$. guineensis fed mostly on phytoplankton, higher plants and detritus. The occurrence of plant fragments have been mentioned in the present study and may be derived from leached paletuvian branches.
According to Winemiller and Kelso-Winemiller (2003) and Zengeya and Marshall (2007), cichlids may incorporate diverse categories of prey including microalgae, macroalgae and detritus in their diets. Concerning $E$. fimbriata, results found in the literature relative to its trophic status are controversial. To our knowledge, Fagade and Olaniyan (1972) were the pioneers in the trophic study of this species in the West African zone. They found that in the early juvenile stage E. fimbriata is zooplanktivore and become phytoplanktophage in adult stage. Adite and Winemiller (1997) indicate that $E$. fimbriata is a detritivorous fish and may be classified in the same group as mullets. More recently, Gning et al. (2008) found that juveniles of this species fed on small 


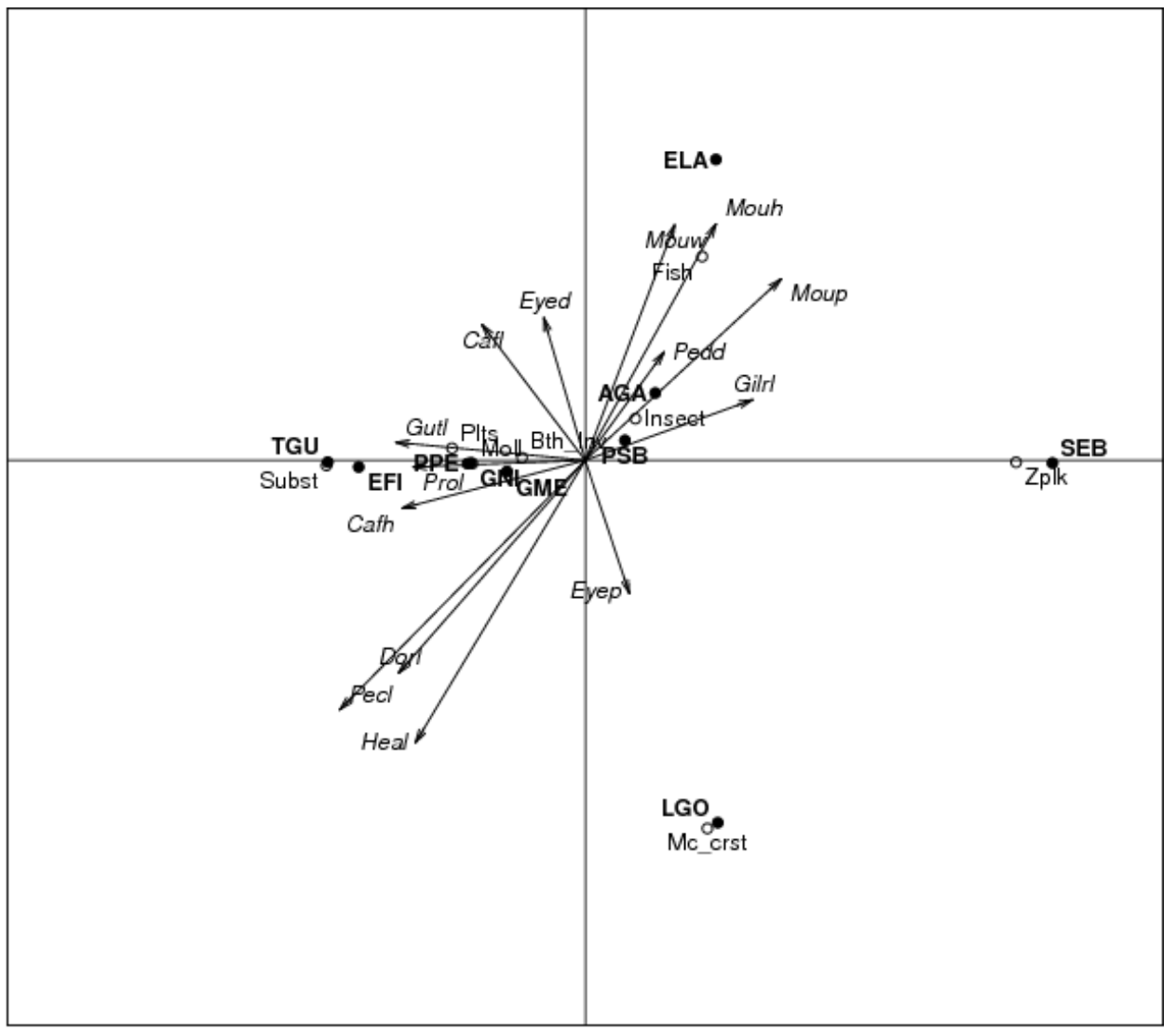

Figure 3. Ordination of the third and the fourth canonical correspondence analysis (CCA) axes based on dietary and morphological variables. See Figure 2 for code signification.

Table 4. Eigenvalues of the unconstrained variables and canonical correlation coefficients for the first four axes of the CCA.

\begin{tabular}{|c|c|c|c|c|}
\hline Axes & $\mathrm{CC} 1$ & $\mathrm{CC2}$ & $\mathrm{CC} 3$ & CC4 \\
\hline \multicolumn{5}{|c|}{ Unconstrained eigenvalues } \\
\hline Moll & 0.89 & 0.96 & 0.49 & 0.01 \\
\hline Fish & 0.47 & -1.1 & -0.51 & -0.9 \\
\hline Mc_crst & 0.5 & -1.13 & -0.53 & 1.62 \\
\hline Bth_Inv & 0.75 & 0.6 & 0.27 & -0.01 \\
\hline Plts & -0.79 & -0.37 & 0.58 & -0.05 \\
\hline Zplk & -1.31 & 1.14 & -1.9 & 0.00 \\
\hline Insect & -0.04 & -0.52 & -0.22 & -0.18 \\
\hline Subst & -1.41 & -0.27 & 1.14 & 0.02 \\
\hline \multicolumn{5}{|c|}{ Canonical correlation values } \\
\hline Pedd & -0.03 & 0.45 & -0.16 & 0.23 \\
\hline Mouh & -0.09 & 0.45 & -0.30 & 0.52 \\
\hline Mouw & -0.43 & 0.43 & -0.20 & 0.52 \\
\hline Eyed & 0.03 & -0.47 & 0.10 & 0.30 \\
\hline Eyep & 0.10 & 0.66 & -0.07 & -0.27 \\
\hline Gilrl & -0.47 & 0.21 & -0.36 & 0.14 \\
\hline Moup & -0.24 & 0.11 & -0.43 & 0.40 \\
\hline Heal & 0.13 & -0.31 & 0.35 & -0.63 \\
\hline Pecl & 0.29 & -0.21 & 0.54 & -0.54 \\
\hline
\end{tabular}


Table 4. Contd.

\begin{tabular}{lllll}
\hline Cafl & $\mathbf{0 . 5 4}$ & -0.11 & 0.39 & -0.13 \\
Cafh & -0.22 & 0.16 & 0.39 & -0.13 \\
Gutl & $\mathbf{- 0 . 5 5}$ & 0.13 & $\mathbf{0 . 4 2}$ & 0.04 \\
Dorl & 0.29 & -0.29 & $\mathbf{0 . 4 1}$ & -0.48 \\
Prol & $\mathbf{0 . 4 1}$ & $\mathbf{- 0 . 5 2}$ & 0.38 & -0.01 \\
\hline
\end{tabular}

Significant coefficients are in bold characters.

benthic invertebrates. The occurrence of benthic invertebrate prey in the diet of E. fimbriata has been reported in the present study in a relatively low proportion. This difference may be linked to a spatial variability in food availability in relation to habitat (Gning et al., 2010).

$S$. maderensis is known as a pelagic species feeding on zooplankton (Cury and Fontana, 1988). The benthic invertebrate feeders group includes $E$. melanopterus, $G$. nigri and $P$. perotaei. These species are found to feed on diverse proportions of molluscs and benthic invertebrates. More, both species are known to feed predominantly on benthic organisms, however they did not totally share the same prey (Albaret and Defossez, 1988; Motta et al., 1995). More recently, Gning et al. (2008) have studied the trophic behaviour of the juveniles of E. melanopterus at a wider spatial scale in the SineSaloun estuary. These authors concluded that this species fed on diverse type of prey including benthic invertebrates (polychaetes, amphipods, euphausiids and mysids) associated with pelagic crustaceans and plant fragments. However, the occurrence of pelagic prey in the diet of E. melanopterus should be explained by the younger stages (juveniles and sub-adults) studied by these authors. The trophic ecology of $P$. perotaei in West African estuaries has been less investigated; the only reported study is that of Longhurst (1957). While Kulbicki et al. (2005) have found that in the Caledonian lagoons, crustaceans contributed to over $60 \%$ in the diet of haemulids. M. sebae has been found to feed on the widest spectra of diet and has been classified as a generalist omnivorous species. The trophic ecology of this species in West African coast is less known. Gning et al. $(2008,2010)$ have addressed this question but their study was limited to the juvenile stages. They concluded that $M$. sebae fed upon a diversity of benthic prey such as polychaetes, insect larvae, shrimps and small crabs associated with small proportion of pelagic prey such as copepods. Except for the presence of fishes in the diet of the largest adult specimen, our findings are in agreement with this result.

The last trophic group included $A$. latiscutatus, $L$. goreensis, and E. lacerta. Except for E. lacerta which showed a strictly piscivorous tendency, this group may be identified as that of macrocarnivores. Studies relative to the trophic status of these demersal fishes in West African ecosystems were scarce (Longhurst, 1957; Diouf,
1996). According to these authors, benthic prey (polychaetes, molluscs and crustaceans) dominated the diet of $A$. latiscutatus and that of $L$. goreensis while $E$. lacerta was a strict piscivore. More, our results are similar to what has been found in other estuarine systems. In the indo-pacific estuarine ecosystems, lutjanid species have been described as piscivores / benthivores and fed on a mixed diet composed of fishes and macrocrustaceans (Wantiez, 1994; Marguillier et al., 1997; Kulbicki et al., 2005). The closeness of piscivores and macrocrustacean feeders in the present study corroborate the conclusion of Wantiez and Chauvet (2003), indicating that a strict piscivory behavior is very scarce.

\section{Ecomorphology}

\section{General pattern}

The results of the CCA indicated that there was a strong interaction between the ecology and the morphological attributes of fishes. Many of the ecomorphological patterns found are in agreement with those compiled from the literature, (Table 5). For example, large mouth gape was fully correlated with piscivory; furthermore long digestive tract was typical for detritivorous fish. Except for the juvenile of $E$. fimbriata which fed on detritus and had a relatively short digestive tract. This controversial pattern may be explained by the fact that the adult of $E$. fimbriata moved to a mixed diet. Herder and Freyhof (2006) found a similar pattern in Rasbora paviei (Cyprinidae). The young of this species feed on detritus and have a dorsally oriented mouth and a relative short gut, while the adult specimens are insectivores. Species which fed on small benthic or pelagic crustaceans had the biggest eye. Both the functional interpretation of eye size and position remain a controversy among functional morphologist communities. For many authors, fishes which foraged in deep zone where light intensity is weak often had the largest eye size (Table 5). In contrast, benthic foragers used barbells pairs to mechanically detect their prey, the eye may be small (Wikramanayake, 1990). Dumay et al. (2004) considered that the occurrence of big eyes is expected in hunting predatory fishes which require a high visual acuity. Furthermore, the occurrence of uppositioned eye in piscivores is in disagreement with 
Table 5. Compilation from the literature of ecomorphological patterns corroborating our own results.

\begin{tabular}{|c|c|c|c|}
\hline Morphological variables & Locomotion/habitat & Trophic behavior & Authors \\
\hline Long digestive tract & & Herbivory / Detritivory & $\begin{array}{l}\text { Wikramanayake (1990); Piet (1998); } \\
\text { Hugueny and Pouilly (1999); Fugi et } \\
\text { al. (2000) }\end{array}$ \\
\hline Mouth gape & & Piscivory & $\begin{array}{l}\text { Sibbing et al. (1994); Sibbing and } \\
\text { Nagelkerke (2001); Xie et al. (2001) }\end{array}$ \\
\hline Up-positioned eyes & Benthic & & Gatz, (1979) \\
\hline $\begin{array}{l}\text { Terminally or dorsally } \\
\text { positioned Mouth }\end{array}$ & Up water column & Piscivory / Zooplankivory & $\begin{array}{l}\text { Gatz (1979); Wikramanayake (1990); } \\
\text { Adite and Winemiller (1997); Piet } \\
\text { (1998) }\end{array}$ \\
\hline Big eyes & $\begin{array}{l}\text { High visual acuity in } \\
\text { benthic or mid-water } \\
\text { column forager }\end{array}$ & Small items feeders & $\begin{array}{l}\text { Piet (1998); Sibbing and Nagelkerke } \\
\text { (2001) }\end{array}$ \\
\hline
\end{tabular}

conclusions found in the literature (Table 5). In contrast, the other ecomorphological patterns are less common in the literature, and require a longer examination.

\section{Feeding function}

Zooplanktivores and detritivores showed a convergent pattern relative to their mouth width and gill raker length. The possession of a relative large mouth in predators feeding on small prey contrasted with the paradigm of close relationship between mouth predator and their prey sizes (Wainwright and Richard, 1995). Both of these morphological attributes refer to the feeding function, though we hypothesized that the observed convergence would be relevant to similarity in food acquisition and processing mechanisms. The two trophic guilds are known to use a suction feeding mode (Wainwright et al., 2001; Wainwright and Bellwood, 2001). Detritivores usually sucked their prey indistinctly with the substratum and then withdraw the non nutritive portion of the bulk sediment by means of their gill raker acting as a barrier (Fugi et al., 2000; Delariva and Agostinho, 2001; Matsumoto and Kokhda, 2001). Zooplanktivores are filter feeders which engulf a large amount of water and then collect the suspended small particles in their gill raker sieve (Hoogenboezem et al., 1991).

Besides, their differences in foraging position and prey type, the two trophic guilds require a wide mouth to either remove an important quantity of sediment or water. Suction feeding modes involves a rapid expansion of buccal cavity followed or not by jaws protrusion which generate a water current and ambient prey rush into the mouth. Benthic invertebrate feeders were characterized by the possession of highly protrusive jaws. The occurrence of protrusive jaws is common in ram-feeder piscivorous fish capturing elusive prey and benthic fish picking individual prey on floor (Wainwright, 1999; Wainwright and Bellwood, 2001; Medeiros and Ramos, 2007). Cochran-Biederman and Winemiller (2010) have found that in cichlids, both piscivorous and benthic invertebrate feeder possessed a long snout and highly protrusive jaws. The efficient use of their protrusive jaws by gerreids as a tool to suck benthic prey has been early reported in Cyrus and Blaber (1983).

Macrocrustacean feeders were discriminated from piscivores by their moderately large oral gap and their long head. According to Sibbing and Nagelkerke (2001) such morphological attributes are expected in fishes which practiced an ambush mode of hunting by overtaking and sucking their prey. Ferreira (2007) have found similar morphological attributes in Hoplias malabaricus, a stream nektonic predator which captures its prey by a rapid strike from an immobilized state.

\section{Locomotive function}

Benthic foraging fish possess long paired fins and either a long or deep caudal fin. These morphological attributes reflect swimming performance, maneuverability and capacity of body orientation and are expected in benthic algal grazer or in other individual prey sucker (Motta et al., 1995; Bellwood et al., 2002; Ferreira, 2007). The important functional role of pectoral fins in food uptake in herbivorous parrotfishes has been highlighted by Rice and Westneat (2005). More, these authors argued that the lack of a ram feeding mode in benthic fishes is compensated by accurate body movement mediated by their pectoral fins and visual acuity.

According to Cochran-Biederman and Winemiller (2010), developed paired fins in benthic fishes may be 
related to the development of other additive behavioral and reproductive tasks. Besides, in piscivores, pectoral and anal fins bases are often short and close to the caudal peduncle (Porter and Motta, 2004). Deep caudal peduncle enhanced drug and is less common in fishes preying upon elusive prey (Gatz, 1979; Freitas et al., 2005). Thus, we consider that the developed caudal peduncle in $L$. goreensis and in E. lacerta should be relevant to a utilization of an ambush foraging mode in agreement with information found in Sibbing and Nagelkerke (2001). According to these authors, fishes using such a foraging mode usually also have deep caudal peduncles. Furthermore, both of these species fed on prey (crabs for $L$. goreensis and juvenile fishes for $E$. lacerta) with low escapement ability.

\section{Conclusion}

The species of different life history traits (juvenile and adult) studied here occupy different functional niches; they are representative of all major trophic groups within the Bamboung marine reserve. Such resource partitioning is associated with a pronounced diversification in morphological attributes of fishes in diverse trophic groups, lowering redundancy, trophic overlap and thus reducing overall competition within this tropical estuary.

These conclusions may contribute to reconciliation between the great diversity of fish assemblages found in estuarine tropical ecosystems and the complexity of their food webs functioning. Ongoing modeling of the Bamboung's fish community will benefit from this input. Altogether, these studies will constitute a rational framework for fisheries management in the areas adjacent to the protected zone.

\section{ACKNOWLEDGEMENTS}

This programme was funded by the ANR AMPHORE. Authors are grateful to the crew of the R/V Diassanga for collecting samples and Pierre Lopez for drawing the map. The authors are also grateful to O. Sadio and J. Raffray for their technical assistance in performing the protocol design of this work.

\section{REFERENCES}

Adite A, Winemiller KO (1997). Trophic ecology and ecomorphology of fish assemblages in coatal lakes of Benin. Ecoscience, 4: 6-23.

Albaret J-J (1994). Les poissons: biologie et peuplements. In: Durand et al. (eds) Environnement et ressources aquatiques de Côte d'Ivoire, Tome II. Les milieux lagunaires, Editions ORSTOM, Paris, pp. 239279.

Albaret J-J (1999). Les peuplements des estuaires et des lagunes. In: Lévêque, C, Paugy, D (eds) Les poissons des eaux continentales africaines : diversité, biologie, écologie et utilisation par l'homme, Éditions de l'IRD, Paris, pp. 325-349.

Albaret J-J, Desfossez P (1988). Biologie et écologie des Gerreidae (pisces, Teleostei) en lagune Ebrié (Côte-d'lvoire). Rev. Hydrobiol. Trop., 21: 71-88.
Bellwood DR, Wainwright PC, Fulton JC, Hoey A (2002). Rules and functional groups at global biogeographical scales. Funct. Ecol., 16: 557-562.

Chuang L-C, Lin Y-S, Liang S-H (2006). Ecomorphological Comparison and Habitat Preference of 2 Cyprinid Fishes, Varicorhinus barbatulus and Candidia barbatus, in Hapen Creek of Northern Taiwan. Zool. Stud., 45: 114-123.

Cochran-Biederman JL, Winemiller KO (2010). Relationships among habitat, ecomorphology and diets of cichlids in the Bladen River, Belize. Env. Biol. Fish., 88: 143-152.

Cury P, Fontana A (1988). Compétition et stratégies démographiques comparées de deux espèces de sardinelles (Sardinella aurita et Sardinella maderensis) des côtes ouest-africaines. Aquat. Living Resour., 1: 165-180.

Cyrus DP, Blaber SJM (1983). The food and feeding ecology of Gerreidae, Bleeker 1859, in the estuaries of Natal. J. Fish Biol., 22: 373-393.

Delariva RL, Agostinho AA (2001). Relationship between morphology and diets of six neotropical loricariids. J. Fish Biol., 58: 832-847.

Diouf PS (1996). Les peuplements de poissons des milieux estuariens de l'Afrique de l'ouest: l'exemple de l'estuaire hyperhalin du SineSaloum, vol. 156. ORSTOM, Paris, 267 pp. Thèse de doctorat, Université

http://www.bondy.ird.fr/pleins_textes/pleins_textes_7/ TDM_7/010008130.pdf.

Dumay O, Tari PS, Tomasini JA, Mouillot D (2004). Functional groups of lagoon fish species in Languedoc Roussillon, southern France. J. Fish Biol., 64: 1-14.

Ecoutin J-M, Simier M, Albaret J-J, Laë R, Tito de Morais L (2010). Changes over a decade in fish assemblages exposed to both environmental and fishing constraints in the Sine Saloum estuary (Senegal). Est. Coast. Shelf Sci., 87: 284-292.

Faye D, Tito de Morais L, Raffray J, Sadio O, Thiaw OT, Le Loc'h F (2011). Structure and seasonal variability of fish food webs in an estuarine tropical marine protected area (Senegal): Evidence from stable isotope analysis. Est. Coast. Shelf Sci., 92: 607-617.

Fagade SO, Olaniyan Cl (1972). The biology of the West African shad Ethmalosa fimbriata (Bodwich) in the Lagos lagoon, Nigeria. J. Fish Biol., 4: 519-533.

Ferreira KM (2007). Biology and ecomorphology of stream fishes from the rio Mogi-Guaçu basin, Southeastern Brazil. Neotrop. Ichthyol., 5: 311-326.

Ferry-Graham LA, Gibb AC, Hernandez LA (2008). Premaxillary movements in Cyprinodontiform fishes: An unusual protrusion mechanism facilitates "picking" prey capture. Zool. 111: 455-466.

Ferry-Graham LA, Wainwright PC, Lauder GV (2003). Quantification of flow during feeding in bluegill sunfish. Zoology, 106: 159-168.

Freitas CEC, Costa EL, Soares MGM (2005). Ecomorphological correlates of thirteen dominant fish species of Amazonian floodplain lakes. Acta Limnol. Bras., 17: 339-347.

Fugi R, Agostinho AA, Hahn NS (2000). Trophic morphology of five benthic-feeding fish species of a tropical floodplain. Revta. Bras. Biol., 6: 27-33.

Gatz AJ (1979). Community organization in fishes as indicated by morphological features. Ecology, 60:711-718.

Gning N, Le Loc'h F, Thiaw OT, Aliaume C, Vidy G (2010). Estuarine resources use by juvenile Flagfin mojarra (Eucinostomus melanopterus) in an inverse tropical estuary (Sine Saloum, Senegal). Est. Coast. Shelf Sci., 86: 683-691.

Gning N, Vidy G, Thiaw OT (2008). Feeding ecology and ontogenic diet shifts of juvenile fish in an inverse estuary: The Sine-Saloum, Senegal. Est. Coast. Shelf Sci., 76: 395-403.

Herder F, Freyhof $J$ (2006). Resource partitioning in a tropical stream fish Assemblage. J. Fish Biol., 69: 571-589.

Hoogenboezem W, van den Boogaart JGM, Sibbing FA, Lammens EHRR, Terlouw A, Osse JWM (1991). A new model of particle retention and branchial sieve adjustment in filter-feeding bream (Abramis brama, Cyprinidae). Can. J. Fish. Aquat. Sci., 48: 7-18.

Horn HS (1966). Measurement of "overlap" in comparative ecological studies. Am. Nat., 100: 419-424.

Hugueny B, Pouilly M (1999). Morphological correlates of diet in an assemblage of West African freshwater fishes. J. Fish Biol., 54: 1310- 
2325.

Ibañez C, Tedesco PA, Bigorne R, Hugueny B, Pouilly M, Zepita C, Zubieta J, Oberdorff T (2007). Dietary-morphological relationships in fish assemblages of small forested streams in the Bolivian Amazon. Aquat. Living Resour., 20: 131-142.

Krebs CJ (1998). Ecological methodology (2nd ed) Addison-Welsey Publishers, Inc., Menlo Park, CA, 120 pp.

Kulbicki M, Bozec Y-M, Labrosse P, Letourneur Y, Mou-Tham G (2005). Diet composition of carnivorous fishes from coral reef lagoons of New Caledonia. Aquat. Living Resour., 18: 231-250.

Longhurst AR (1957). The food of the demersal fish of a west African estuary. J. Anim. Ecol., 26: 369-387.

Marguillier S, Van der Velde G, Dehairs F, Hemminga MA, Rajogopal S (1997). Trophic relationships in an interlinked mangroves seagrass ecosystem as traced by $\delta^{13} \mathrm{C}$ and $\delta^{15} \mathrm{~N}$. Mar. Ecol. Prog. Ser., 151: 115-121.

Matsumoto K, Kohda M (2001). Differences in gill raker morphology between two local populations of a benthophageous filter-feeding fish, Goniistius zonatus (Cheilodactylidae). Ichthyol. Res., 48: 269273.

Medeiros PR, Ramos RT (2007). Predicting ecomorphological patterns from morphology of a tropical estuarine fish assemblage. Bioc. Porto Alegre, 15: 40-46.

Motta PJ, Clifton KB, Hernandez P, Eggold BT (1995). Ecomorphological correlates in ten species of subtropical seagrass fishes: diet and microhabitat. Environ. Biol. Fish., 44: 37-60.

Norton SF, Brainerd EL (1993). Convergence in feeding mechanics of ecomorphologically similar species in the Centrarchidae and Chichlidae. J. Exp. Biol., 176: 11-29.

Norton SF, Luczkovich JJ, Motta JP (1995). The role of ecomorphological studies in comparative biology of fishes. Env. Biol. Fish., 44: 287-304.

Offem BO, Samsons YA, Omoniyi IT (2009). Trophic ecology of commercially important fishes in the cross river, Nigeria. J. A. Plant Sci., 19: 37-44.

Pianka ER (1969). Sympatry of desert lizards (CTENOTUS) in Western Australia. Ecology, 50: 1012-1030.

Piet GJ (1998). Ecomorphology of a size-structured tropical freshwater fish community. Environ. Biol. Fish., 51: 67-86.

Ponton D, Mérigoux S (2000). Comparative morphology and diet of young cichlids in the dammed Sinnamary River, French Guiana, South America. J. Fish Biol., 56: 87-102.

Porter HT, Motta PJ (2004). A comparison of strike and prey capture kinematics of three species of piscivorous fishes: Florida gar (Lepisosteus platyrhincus), redfin needlefish (Strongylura notata), and great barracuda (Sphyraena barracuda). Mar. Biol., 145: 9891000.

Pouilly M, Lino F, Bretenoux JG, Rosales C (2003). Dietarymorphological relationships in a fish assemblage of the Bolivian Amazonian floodplain. J. Fish Biol., 62: 1137-1158.

R Development Core Team (2010). R: A language and environment for statistical computing. R Foundation for Statistical Computing,Vienna, Austria. ISBN 3-900051-07-0, URL http://www.R-project.org.

Rakocinski CF, Lyczkowski-Shulz J, Richardson SL (1996). Ichtyoplankton assemblage structure in Mississippi Sound as revealed by Canonical Correspondence Analysis. Est.Coast. Shelf Sci., 43: 237-257.

Rice AN, Westneat MW (2005). Coordination of feeding, locomotor and visual systems in parrotfishes (Teleostei: Labridae). J. Exp. Biol., 208: 3503-3518.

Ross ST (1986). Resource partitioning in fish assemblages: A review of field studies. Copeia, 1986: 352-388.

Schoener TW (1974). Resources partitioning in ecological communities. Science, 185: 27-39.

Sibbing FA, Nagelkerke LAJ (2001). Resource partitioning by Lake Tana barbs predicted from fish morphometrics and prey characteristics. Rev. Fish Biol. Fish., 10: 393-437.
Sibbing FA, Nagelkerke LAJ, Osse JWM (1994). Ecomorphology as a tool in fisheries: identification and ecotyping of Lake Tana Barbs (Barbus intermedius complex), Ethiopia. Neth. J. Agric. Sci., 42: 7785.

Sibbing FA, Nagelkerke LAJ, Stet RJM, Osse JWM (1998). Speciation of endemic Lake Tana barbs (Cyprinidae, Ethiopia) driven by trophic resource partitioning; a molecular and ecomorphological approach. Aquat. Ecol., 32: 217-227.

Simier M, Blanc L, Aliaume C, Diouf PS, Albaret J-J (2004). Spatial and temporal structure of fish assemblages in an "inverse estuary", the Sine-Saloum system (Senegal). Est. Coast. Shelf Sci., 59: 69-86.

Sow I, Guillard J (2010). Suivi par hydroacoustique du peuplement piscicole d'une Aire Marine Protégée du Sine-Saloum (Sénégal): bilan 2003-2007. J. Sci. Halieut. Aquat., 1: 21-32.

Ter Braak CJF (1986). Canonical Correspondence Analysis: A new eigenvector technique for multivariate direct gradient analysis. Ecology, 67: 167-1179.

Wainwright PC (1994). Functional morphology as a tool in ecological research. In: Wainwright, PC, Reilly, SM (eds) Ecological morphology: integrative organismal biology, University of Chicago Press, Chicago, pp. 42-59.

Wainwright PC (1999). Ecomorphology of prey capture in fishes. In: Saksena, E (eds) Advances in Ichthyological Research, Jiwaji: University Press, Gwalior India, pp. 375-387.

Wainwright PC, Bellwood DR (2001). Ecomorphology of feeding in Coral Reef fishes. In: PB131A Sale (eds), Coral Reef Fishes Academic Press, p. 33-56.

Wainwright PC, Bellwood DR, Westneat MW (2002). Ecomorphology of locomotion in labrid fishes. Env. Biol. Fish. 65: 47-62.

Wainwright PC, Ferry-Graham LA, Waltzek TB, Carroll AM (2001). Evaluating the use of ram and suction during prey capture by cichlid fishes. J. Exp. Biol., 204: 3039-3051.

Wainwright PC, Richard BA (1995). Predicting patterns of prey use from morphology with fishes. Env. Biol. Fish., 44: 97-113.

Wantiez L (1994). Réseaux trophiques de l'ichtyofaune des fonds meubles lagonaires de Nouvelle-Calédonie. Compt. Rendus Acad Sci. III Sci. Vie, 317: 347-359.

Wantiez L, Chauvet C (2003). First data on community structure and networks of Uvea coral reef fish assemblages (Wallis and Futuna, South Pacific Ocean). Cybium, 27: 83-100.

Wikramanayake ED (1990). Ecomorphology and Biogeography of a Tropical Stream Fish Assemblage. Evol. Assemblage Struct. Ecol., 71: $1756-1764$.

Willis SC, Winemiller, KO, Lopez-Fernandez H (2005). Habitat structural complexity and morphological diversity of fish assemblages in a Neotropical floodplain river. Oecologia, 142: 284-295.

Winemiller KO (1990). Spatial and temporal variation in tropical fish trophic networks. Ecol. Monogr., 60: 331-367.

Winemiller KO (1991). Ecomorphological Diversification in Lowland Freshwater Fish Assemblages from five biotic regions. Ecol. Monogr., 61: 343-365.

Winemiller KO, Kelso-Winemiller LC (2003). Food habits of tilapine cichlids of the upper Zambezi River and floodplain during the descending phase of the hydrologic cycle. J. Fish Biol., 63: 120-128.

Winemiller KO, Kelso-Winemiller LC, Brenkert AL (1995). Ecomorphological diversification and convergence in fluvial cichlid fishes. Env. Biol. Fish., 44: 235-261.

Xie S, Cui Y, Li Z (2001). Dietary-morphological relationships of fishes in Liangzi Lake, China. J. Fish Biol., 58: 1714-1729.

Zengeya TA, Marshall BE (2007). Trophic interrelationships amongst cichlid fishes in a tropical African Reservoir, (Lake Chivero, Zimbabwe). Hydrobiology, 592: 175-182. 


\section{APPENDIX}

Appendix 1. Getting functional traits ratios from morphometric measurements.

\begin{tabular}{|c|c|}
\hline Functional traits & Ratios \\
\hline Gill raker length & $\frac{G r L}{H D}$ \\
\hline Eye position & $\frac{E P}{H D}$ \\
\hline Mouth position & $\frac{M P}{H D}$ \\
\hline Caudal peduncle depth & $\frac{C p D}{B D}$ \\
\hline Mouth height & $\frac{M H}{B D}$ \\
\hline Mouth width & $\frac{M W}{B W}$ \\
\hline Eye diameter & $\frac{E D}{H L}$ \\
\hline Head length & $\frac{H L}{S L}$ \\
\hline Pectoral fins length & $\frac{P f L}{S L}$ \\
\hline Caudal fin depth & $\frac{C f D}{S L}$ \\
\hline Caudal fin length & $\frac{C f L}{S L}$ \\
\hline Digestive tract length & $\frac{G u L}{S L}$ \\
\hline Dorsal fin length & $\frac{D f L}{S L}$ \\
\hline Protrusion length & $\frac{\operatorname{Pr} L}{S L}$ \\
\hline
\end{tabular}

Codes signification: GrL: gill raker length ; HD: head depth ; Ep: eye position ; Mp: mouth position ; CpD: caudal peduncle depth; BD: body depth ; BW: body width; MH: mouth height ; MW: mouth width ; ED: eye diameter; HL: Head length; SL: standard length; PfL: pectoral fin length; Cfd: caudal fin depth; CfL: caudal fin length; GuL: gut length; DfL: dorsal fin length; PrL: protrusion length. 
Appendix 2. Prey's proportions in the diet of the ten species analysed in the study.

\begin{tabular}{|c|c|c|c|c|c|c|c|c|c|c|}
\hline & AGA & EFI & ELA & GME & GNI & LGO & PPE & PSB & SEB & TGU \\
\hline Number of sample & 91 & 100 & 15 & 58 & 26 & 20 & 29 & 54 & 28 & 15 \\
\hline Mean size (FL mm) & 331.3 & 95.2 & 95.6 & 111.3 & 402.3 & 238.9 & 98.7 & 124.0 & 98.7 & 212.1 \\
\hline \multicolumn{11}{|c|}{ Benthic invertebrates } \\
\hline Amphipods & 0.0 & 0.0 & 0.0 & 58.8 & 19.0 & 0.0 & 0.0 & 4.5 & 0.0 & 0.0 \\
\hline Ascidians & 11.5 & 0.0 & 0.0 & 0.0 & 0.0 & 0.0 & 0.0 & 0.0 & 0.0 & 0.1 \\
\hline Echinoderms & 0.2 & 0.0 & 0.0 & 0.0 & 0.0 & 0.0 & 0.2 & 0.0 & 0.0 & 0.0 \\
\hline Isopods & 0.0 & 0.0 & 0.0 & 5.7 & 0.1 & 0.0 & 0.0 & 0.0 & 0.0 & 0.0 \\
\hline Ostracods & 0.0 & 0.2 & 0.0 & 0.0 & 0.0 & 0.0 & 0.0 & 0.0 & 0.0 & 0.0 \\
\hline Polychaetes & 0.2 & 0.0 & 0.0 & 1.6 & 0.0 & 0.0 & 0.5 & 1.2 & 2.3 & 0.0 \\
\hline Tanaids & 1.5 & 0.0 & 0.0 & 0.2 & 1.4 & 0.0 & 13.8 & 1.2 & 0.0 & 0.0 \\
\hline Thallassinids & 1.1 & 0.0 & 0.0 & 5.4 & 1.6 & 0.0 & 0.0 & 0.1 & 0.0 & 0.0 \\
\hline Fish & 53.1 & 0.0 & 100 & 0.0 & 0.0 & 20.2 & 0.0 & 20.2 & 0.0 & 0.0 \\
\hline Insects & 0.5 & 0.0 & 0.0 & 0.0 & 0.0 & 0.0 & 0.0 & 2.6 & 0.0 & 0.0 \\
\hline \multicolumn{11}{|l|}{ Macrocrustaceans } \\
\hline Crabs & 17.4 & 0.0 & 0.0 & 2.2 & 0.0 & 76.0 & 0.0 & 5.6 & 0.0 & 0.0 \\
\hline Penaieds & 0.0 & 0.0 & 0.0 & 0.0 & 0.0 & 0.0 & 0.0 & 3.7 & 0.0 & 0.0 \\
\hline \multicolumn{11}{|l|}{ Molluscs } \\
\hline Bivalves & 9.5 & 0.0 & 0.0 & 20.8 & 63.0 & 1.0 & 79.1 & 0.4 & 0.0 & 0.0 \\
\hline \multirow{2}{*}{ Gastropodes } & 0.1 & 0.0 & 0.0 & 0.8 & 12.0 & 0.0 & 2.1 & 0.5 & 0.0 & 0.0 \\
\hline & 0.0 & 0.0 & 0.0 & 0.0 & 0.0 & 0.0 & 2.2 & 0.0 & 0.0 & 0.0 \\
\hline \multicolumn{11}{|l|}{ Zooplankton } \\
\hline Copepods & 0.0 & 0.0 & 0.0 & 0.0 & 0.0 & 0.0 & 0.0 & 0.0 & 15.9 & 0.0 \\
\hline Crustaceans larvae & 0.0 & 0.0 & 0.0 & 0.0 & 0.0 & 0.0 & 0.0 & 4.5 & 38.2 & 0.0 \\
\hline Euphausid & 0.0 & 0.0 & 0.0 & 0.0 & 0.0 & 0.0 & 0.0 & 0.0 & 0.2 & 0.0 \\
\hline Micro-gastropods & & 7.5 & 0.0 & 0.0 & 0.0 & 0.0 & 0.0 & 3.2 & 35.3 & 0.0 \\
\hline Mysids & 0.0 & 0.0 & 0.0 & 0.0 & 0.0 & 0.0 & 0.0 & 0.0 & 0.1 & 0.0 \\
\hline \multicolumn{11}{|l|}{ Plants } \\
\hline Wood fragments & 0.0 & 1.6 & 0.0 & 0.0 & 0.7 & 0.0 & 0.4 & 20.0 & 0.0 & 22.3 \\
\hline Mangroves leaves & 0.3 & 0.0 & 0.0 & 0.0 & 0.0 & 0.0 & 0.0 & 0.0 & 0.0 & 0.0 \\
\hline Substratum & 0.8 & 89.5 & 0.0 & 0.0 & 0.5 & 0.0 & 0.0 & 4.4 & 0.0 & 77.5 \\
\hline Unidentified prey & 1.4 & 0.0 & 0.0 & 4.2 & 1.2 & 2.5 & 1.2 & 19.0 & 7.7 & 0.0 \\
\hline
\end{tabular}

The eight functional prey categories are in bold characters. The taxonomically undetermined items and mashed food were gathered as unidentified prey. The mean size (Fork length, $\mathrm{mm}$ ) and the number of samples (with full stomach) per specie are indicated. AGA: Arius latiscutatus; EFI: Ethmalosa fimbriata; ELA: Elops lacerta; GME: Eucinostomus melanopterus; GNI: Gerres nigri; LGO: Lutjanus goreensis; PPE: Pomadasys perotaei; PSB: Monodactylus sebae; SEB: Sardinella maderensis; TGU: Tilapia guineensis. 